\title{
Fulminant encephalopathy in a child with hyperferritinemic sepsis: a case report
}

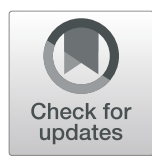

Lilin Huang ${ }^{*}$, Shumei Peng, Ronghan Li, Danyu Xie and Dongping Huang

\begin{abstract}
Background: Sepsis-associated encephalopathy (SAE) is epidemic in intensive care units and recognized as a fatal complication of sepsis. SAE is characterized by diffuse brain dysfunction and the correct diagnosis of SAE requires ruling out direct central nervous system (CNS) infection or other types of encephalopathy, such as hepatic encephalopathy, pulmonary encephalopathy, and other encephalopathy.

Case presentation: We reported a rare case of a 5-year-old girl who presented with abdominal pain, vomiting, recurrent seizures, and coma. Brain magnetic resonance imaging (MRI) showed diffuse white matter abnormalities in the brain on day 1. Cerebrospinal fluid (CSF) tests revealed that protein levels and glucose levels were normal without pleocytosis. CSF PCRs for pathogens were all negative. The electroencephalography examination demonstrated diffuse, generalized and slow background activity. The patient showed the symptom of hyperferritinemic sepsis with multiple organ dysfunction syndrome (MODS). SAE was also diagnosed by ruling out other encephalitis or encephalopathy. The patient made marked improvements of clinical symptoms and the lesions on brain imaging disappeared completely within two months after appropriate treatment including antibiotic treatments, methylprednisolone, intravenous immunoglobulin, membrane-based therapeutic plasma exchange (TPE), and continuous renal replacement therapy (CRRT).

Conclusions: SAE can be a fatal complication of sepsis which asks for immediate diagnosis and treatment. Few reports have focus on MRI imaging findings on the early onset of hyperferritinemic sepsis with MODS since these children were too ill to undergo an MRI scan. However, SAE might appear before other systemic features of sepsis are obvious, and MRI could show abnormal lesion in the brain during the early course. Therefore, MRI should be performed early to diagnose this fatal complication which would play important roles in improving the clinical outcomes by early initiation with appropriate treatments.
\end{abstract}

Keywords: Fulminant, Sepsis-associated encephalopathy, Hyperferritinemic sepsis, Diffuse white matter abnormalities

\section{Background}

Sepsis-associated encephalopathy (SAE) is epidemic in intensive care units and has received a large amount of attention [1]. The correct diagnosis of SAE requires ruling out direct central nervous system (CNS) infection or other types of encephalopathy (such as hepatic encephalopathy, pulmonary encephalopathy, and other encephalopathy)

\footnotetext{
* Correspondence: 921295597@qq.com
}

Department of Pediatrics, Guangdong Women and Children Hospital, Guangzhou, Guangdong, China
[2]. There is no consensus about specific and effective treatments for SAE, as how its pathogenesis occurs is still unclear. There are few pediatric cases of SAE reported, and all had long stays in the ICU with poor prognoses. Herein, we report that a child with severe hyperferritinemic SAE was successfully treated within 2 months. To our knowledge, this is the first study describing brain magnetic resonance imaging (MRI) of a patient with hyperferritinemic sepsis on the day one after the onset of symptoms since these children are often too ill to undergo an MRI

(c) The Author(s). 2020 Open Access This article is licensed under a Creative Commons Attribution 4.0 International License, which permits use, sharing, adaptation, distribution and reproduction in any medium or format, as long as you give appropriate credit to the original author(s) and the source, provide a link to the Creative Commons licence, and indicate if changes were made. The images or other third party material in this article are included in the article's Creative Commons licence, unless indicated otherwise in a credit line to the material. If material is not included in the article's Creative Commons licence and your intended use is not permitted by statutory regulation or exceeds the permitted use, you will need to obtain permission directly from the copyright holder. To view a copy of this licence, visit http://creativecommons.org/licenses/by/4.0/ The Creative Commons Public Domain Dedication waiver (http://creativecommons.org/publicdomain/zero/1.0/) applies to the data made available in this article, unless otherwise stated in a credit line to the data. 
scan upon presentation. The fulminant clinical features and extensive brain lesions throughout the white matter suggested that the patient was in an extremely dangerous state. However, the patient in our case recovered quickly, and the lesions on brain imaging were reversed completely upon accurate diagnosis and effective treatment.

\section{Case presentation}

A previously healthy 5-year-old girl was admitted to the first hospital on January 17, 2018, with symptoms of abdominal pain, vomiting, and new-onset refractory status epilepticus (NORSE) that had lasted for $4 \mathrm{~h}$. The results of a cranial computed tomography $(\mathrm{CT})$ performed by the emergency department were normal. She was transferred to our hospital $6 \mathrm{~h}$ after onset, demonstrating signs of coma, tachypnea, and tachycardia. Her past medical history was negative. Upon admission, her body temperature was $36.3^{\circ} \mathrm{C}$, her heart rate was 155 beats/min, her respiratory rate was 50 breaths/min, her blood pressure was 102/67 $\mathrm{mmHg}$, and the Glasgow Coma Scale score (GCS) was E1V1M3. Hypermyotonia was observed in both limbs, and the Babinski sign was positive bilaterally. Other findings from the systemic physical examinations were unremarkable. Percutaneous oxygen saturation measured by pulse oximetry ( $\mathrm{SpO} 2)$ was $93-95 \%$ on $25 \% \mathrm{FiO}_{2}$. A series of blood tests showed the white blood cell (WBC) count to be $15.98 \times 10^{9} / \mathrm{L}$, neutrophils $91.3 \%$, lymphocytes $4.8 \%$, red blood cells $4.99 \times 10^{12} / \mathrm{L}$, platelets $264 \times 10^{9} / \mathrm{L}$, CRP $2.5 \mathrm{mg} /$ $\mathrm{L}$, procalcitonin (PCT) $55.77 \mathrm{ng} / \mathrm{mL}$, ferritin $120 \mathrm{ng} / \mathrm{ml}$, coagulant function (fibrin $1.53 \mathrm{~g} / \mathrm{L}$, D-Dimer $0.27 \mathrm{mg} / \mathrm{L}$, prothrombin time (PT) $12.2 \mathrm{~s}$, activated partial thromboplastin time (APTT) $24.9 \mathrm{~s}$, INR 1.04, ACT 85\%), serum enzymes (CKMB 24U/L, CK $298 \mathrm{U} / \mathrm{L}, \mathrm{LDH} 797 \mathrm{U} / \mathrm{L}$, aspartate transaminase (AST) $65 \mathrm{IU} / \mathrm{L}$, alanine transaminase (ALT), $38 \mathrm{IU} / \mathrm{L}$ ), creatinine $40.7 \mu \mathrm{mol} / \mathrm{L}$, and BUN $4.34 \mathrm{mmol} / \mathrm{L}$. Brain magnetic resonance imaging (MRI) was performed quickly when the patient was admitted to our hospital. The diffusion-weighted imaging (DWI) scan of the patient's brain on admission showed symmetric areas with high signal intensity in the periventricular white matter involving the centrum semiovale and the corona radiate (Fig. 1 a-d). The patient had rapid clinical deterioration that developed to hyperferritinemic sepsis with multiple organ dysfunction syndrome (MODS) $15 \mathrm{~h}$ after onset, including exhibiting a worsening mental status (GCS E1V1M1), fever $\left(40.6^{\circ} \mathrm{C}\right)$, hypotension $(60 / 47 \mathrm{mmHg})$, tachycardia (heart rate: 178 beats $/ \mathrm{min}$ ), and tachypnea (respiratory rate: 70 breaths/min). She was intubated, and a vasopressor was quickly given to maintain blood pressure. A repeat blood test showed a WBC count of $9.09 \times 10^{9} / \mathrm{L}$, neutrophils $71.4 \%$, lymphocytes $18.8 \%$, red blood cells $4.49 \times 10^{12} / \mathrm{L}$, platelets $27 \times 10^{9} / \mathrm{L}$, ferritin $22,579.1 \mathrm{ng} /$ $\mathrm{ml}$, coagulant dysfunction (fibrin $1.5 \mathrm{~g} / \mathrm{L}$, D-dimer, 4.7
mg/L, PT 31.4s, APTT 74.1 s, INR2.79, ACT 20.2\%,), serum enzymes (CKMB $55 \mathrm{U} / \mathrm{L}$, CK $1529 \mathrm{U} / \mathrm{L}, \mathrm{LDH}$ $2550 \mathrm{U} / \mathrm{L}$, AST $295 \mathrm{IU} / \mathrm{L}$, ALT $114 \mathrm{IU} / \mathrm{L})$, creatinine $134.3 \mu \mathrm{mol} / \mathrm{L}$, and BUN $10.82 \mathrm{mmol} / \mathrm{L}$. Blood cultures did not identify any pathogens. Serum viral studies (influenza A and B viruses, respiratory syncytial virus, adenoviruses, cytomegalovirus, Epstein-Barr virus, hepatitis $\mathrm{C}$ virus, hepatitis $B$ virus, and human immunodeficiency virus) and serology tests for syphilis, Mycoplasma pneumonia and Mycobacterium tuberculosis were all negative. Lumber punctures were performed 3 times, and showed increased intracranial pressure (the highest was over 300 $\mathrm{mm} \mathrm{H}_{2} \mathrm{O}$ ). Cerebrospinal fluid (CSF) tests revealed that protein levels and glucose levels were normal without pleocytosis. CSF PCRs for enterovirus, herpes simplex virus, cytomegalovirus, Epstein-Barr virus, and tuberculosis were all negative. CSF bacterial and fungal cultures were also negative. The echocardiographic results showed that the left ventricular ejection fraction was $52 \%$. The electrocardiograph (ECG) showed tachycardia. The electroencephalography examination demonstrated diffuse, generalized and slow background activity. X-ray imaging showed the presence of bronchitis. Hyperferritinemic sepsis was diagnosed after ruling out haemophagocytic lymphohistiocytosis (HLH) since the diagnostic criteria for HLH were not fulfilled in this girl. SAE was also diagnosed by ruling out encephalitis, meningitis, acute necrotizing encephalopathy, acute disseminated encephalomyelitis, Guillain-Barre syndrome, cerebral vasculitis, and metabolic encephalopathy, according to laboratory tests and imaging features. Integrated treatment was initiated on admission, which included anti-infection treatments (meropenem, vancomycin, and voriconazole), anti-inflammation treatments (methylprednisolone, $15 \mathrm{mg} / \mathrm{kg} /$ day $\times 3$ days), intravenous immunoglobulin $(1 \mathrm{~g} / \mathrm{kg} /$ day $\times 2$ days $)$, and frozen plasma as well as the administration of other medicines for hepatic and myocardial protection. The symptoms were not relieved, and the fulminant development of MODS indicated that hyperinflammation or an autoimmune response might be involved. Membrane-based therapeutic plasma exchange (TPE) was started on day 3 since it can eliminate pro-inflammatory cytokines rapidly and can modulate the sepsis cascade. The exchange volume was 1.5 -fold the patient's plasma volume. Plasma volume was estimated as follows: plasma volume (in liters) $=$ $0.07 \times$ weight $(\mathrm{kg}) \times(1$-hematocrit $)$ [3]. The removed plasma was substituted with fresh frozen plasma at a 1:1 ratio in our patient. The first three TPEs were performed daily. After the second TPE, the patient needed less vasopressor. By the third TPE treatment, liver enzymes had decreased. The patient was extubated and regained full consciousness on day 10, with mild remaining disseminated intravascular coagulation (DIC), acute kidney injury (AKI) and capillary leak syndrome (CLS). The last two 

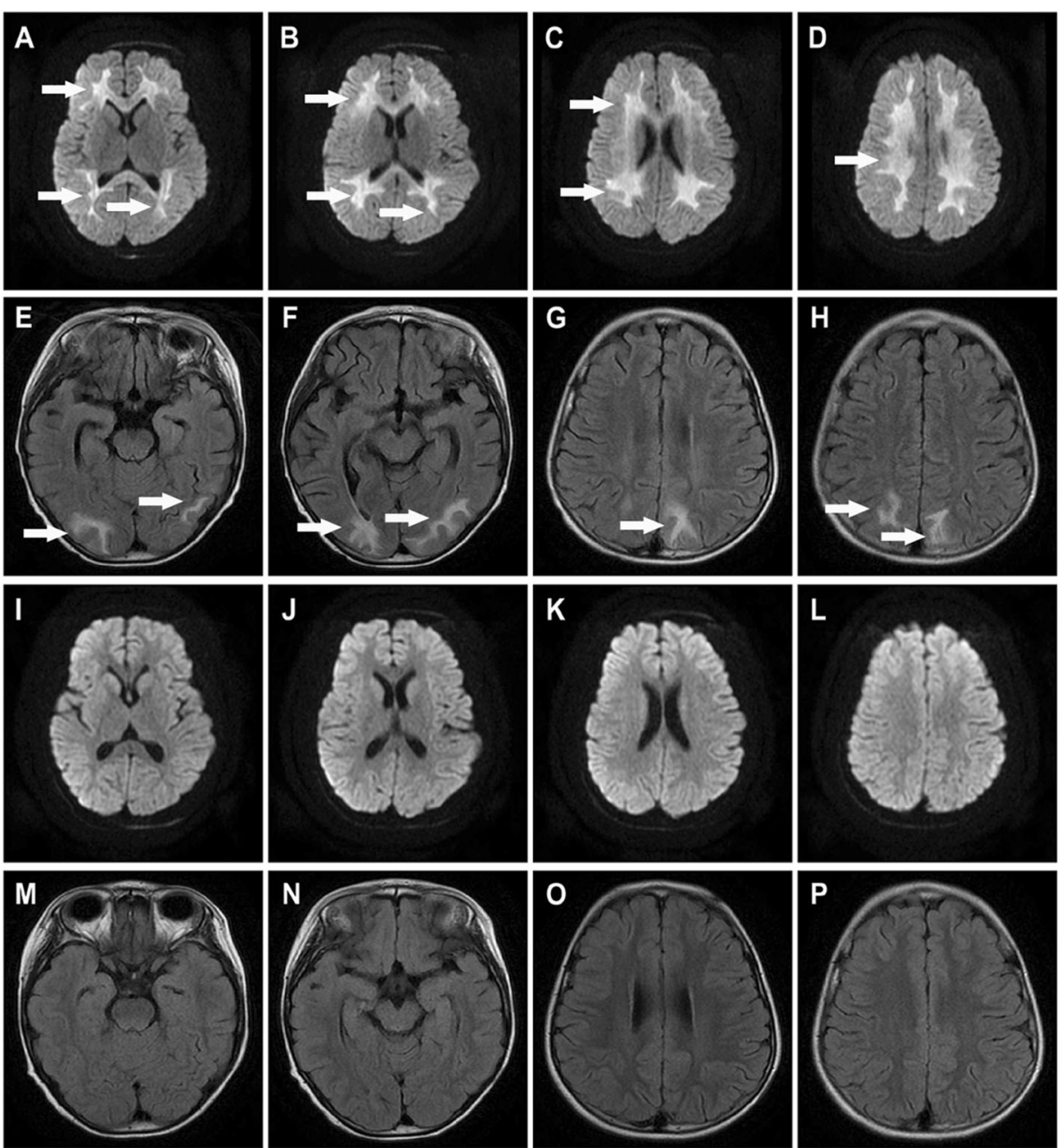

Fig. 1 Brain magnetic resonance imaging (MRI) (a-d) DWI showed symmetric areas of high signal intensity in the periventricular white matter involving the centrum semiovale and corona radiate on day 1 (white arrow). (e-h) T2/FLAIR images showed diffuse high signal intensity in the white matter of occipital and parietal regions on day 17(white arrow). (i-p) DWI and T2/FLAIR images showed brain lesions had completely disappeared in the white matter on day 55

TPEs were followed by continuous vena-venous hemofiltration $(\mathrm{CVVH}) 2$ times to remove creatinine and BUN, to prevent liquid overload and to maintain coagulation function. After these integrated treatments, clinical and laboratory improvement were monitored in the patient (Table 1). Echocardiography showed that left ventricular systolic function was normalized, with a left ventricular ejection fraction (LVEF) of 62\%. The ECG was normal. Her muscle strength gradually improved, showing increased movements, and she was able to walk short distances 17 days after onset. At this point, repeated brain MRI showed that the lesions were reduced, and T2/FLAIR scans indicated diffuse high signal intensity in the white matter of the occipital and parietal regions (Fig. 1 e-h). The patient was transferred to a rehabilitation center 21 days after onset. She had regained full independence in activities of daily living at 55 days after onset. A repeat brain
MRI showed that the lesions had completely disappeared in the white matter regions (Fig. $1 \mathrm{i}$-p).

\section{Discussion and conclusions}

MRI imaging finding on day 1 after onset of hyperferritinemic sepsis with SAE are rarely reported in pediatric patients. However, MRI could show abnormal lesion in the brain during the early course of SAE, which might contribute to appropriate management and therefore improve the prognosis of sepsis. The patient in our study presented with NORSE even though she was administered diazepam and phenobarbital. The symptom of NORSE last hours in our patient which indicated longterm consequences (after time point $t_{2}$ ), including neuronal death, neuronal injury, and impaired consciousness $[4,5]$. As expected, the imaging of MRI indicated diffuse lesion in her brain. It is very important to recognized 
Table 1 Laboratory parameters for the patient

\begin{tabular}{|c|c|c|c|c|c|}
\hline & Pre TPE & status post one TPE & status post two TPE & status post three TPE & status post last TPE \\
\hline Hospital day & 1 & 3 & 4 & 10 & 13 \\
\hline $\operatorname{WBC}\left(\times 10^{9} / L\right)$ & 9.09 & 8.67 & 8.16 & 5.7 & 11.28 \\
\hline neutrophil $\left(\times 10^{9} / L\right)$ & 6.49 & 7.68 & 7.15 & 5.22 & 10.1 \\
\hline Platelet $\left(\times 10^{9} / \mathrm{L}\right)$ & 27 & 37 & 73 & 30 & 151 \\
\hline CRP (mg/L) & 2.5 & 2.5 & 2.5 & - & 2.5 \\
\hline PCT (ng/mL) & 55.77 & - & 21.82 & 20.54 & 0.21 \\
\hline Ferritin (ng/mL) & $22,579.1$ & 5246.03 & - & 1238.96 & - \\
\hline APTT(s) & 74.1 & 43.3 & 31.5 & 34.8 & 31.7 \\
\hline PT(s) & 31.4 & 23.5 & 18.1 & 20.5 & 12.8 \\
\hline Fib(g/L) & 1.5 & 1.39 & 2.01 & 1.25 & 1.31 \\
\hline D-dimer (mg/L) & 4.7 & 34.72 & 12.78 & 28.16 & 13.51 \\
\hline Creatine $(\mu \mathrm{mol} / \mathrm{L})$ & 134.3 & 96.8 & 159.1 & 213.6 & 68.4 \\
\hline BUN (mmol/L) & 10.82 & 9.03 & 12.99 & 23.29 & 10.31 \\
\hline ALT(U/L) & 114 & 422 & 2580 & 1686 & 212 \\
\hline AST(U/L) & 295 & 667 & 3415 & 1764 & 71 \\
\hline CKMB(U/L) & 55 & 48 & - & 28 & 18 \\
\hline
\end{tabular}

NORSE quickly and require immediate interventions. NORSE is etiologically heterogeneous which may occur in patients with various encephalitis/encephalopathy, such as infectious encephalitis/encephalopathy, autoimmune encephalitis, and metabolic encephalopathy. Therefore, looking for the underlying causes can contribute to treatment correspondingly. NORSE in SAE is not rare. SAE can be found in up to $70-80 \%$ of patients with sepsis in intensive care units and can be an independent determinant for a poor prognosis $[1,6,7]$. There was a study that indicated that SAE can be an early feature of infection in the body and that it might appear before other systemic features of sepsis are obvious [8]. Tachypnea can be a feature of early SAE. Therefore, SAE can be latent but fatal in some patients; thus, distinguishing SAE early is very important for these patients. No specific biomarker exists for SAE, and it remains largely a clinical diagnosis [2, 9]. The blood tests showed that the WBC count, the proportion of neutrophils and PCT were very high in our patient which indicated the existence of bacterial infection. In particular, PCT was $55.77 \mathrm{ng} / \mathrm{mL}$, which was helpful to differentiate system inflammatory reaction syndrome due to virus or autoimmune disease from bacterial sepsis. Furthermore, the amino acids and acylcarnitine results in the blood and urine organic acids excluded genetic metabolic diseases. Plasma ammonia was normal in this patient, including test for tetramines, organophosphorus pesticides, and sedatives, which were all negative in this patient. The patient did not show symptoms of skin rash or arthralgia. The antinuclear antibody spectrum was negative. There was no sign of autoimmune diseases, such as juvenile idiopathic arthritis, systemic lupus erythematosus, or vasculitis. The symptoms of this patient included fever, ferritin $>500 \mathrm{ng} / \mathrm{mL}$, hypofibrinogenemia, and hemophagocytosis. These did not fulfill five of the eight criteria for HLH. Therefore, hyperferritinemic sepsis associated with MODS was diagnosed in our patient. We did not detect the autoimmune antibodies associated autoimmune encephalitis in this patient since she showed obvious symptoms of fulminant sepsis with MODS without outstanding symptoms of behavior, psychosis, or memory impairment. Additionally, the hyperferritinemia and high levels of PCT are rare in patients with autoimmune encephalitis.

A few pediatric cases of SAE have been reported, but they had poor prognoses. Neuroimaging in these patients with SAE was anfractuous. In this study, we collected data from 18 available cases of SAE (including 3 pediatric cases and 15 adult cases) in the literature, and the MRI features and prognoses are shown in Table 2. The data suggested that MRI results can be normal, or they can show multiple ischemic strokes, multiple microbleeds or white matter lesions in the periventricular areas and centrum semiovale in patients with SAE. The severity of lesions in the brain is positively correlated with the severity of sepsis, while it is inversely correlated with GCS scores [8]. The diffuse and severe white matter abnormalities in our case were rare and have been reported to be associated with poor outcomes in other patients with extensive white matter lesions [12]. Fortunately, MRI was performed during the early course of SAE in our case, which contributed to a favorable prognosis. However, apparent diffusion coefficient 
Table 2 MRI features and prognosis of the patients with SAE in the literatures

\begin{tabular}{|c|c|c|c|c|}
\hline $\begin{array}{l}\text { Patient } \\
\text { No.(reference) }\end{array}$ & Age/sex & $\begin{array}{l}\text { Days from sepsis } \\
\text { onset to MRI }\end{array}$ & MRI lesion & Outcome \\
\hline $1[10]$ & $\begin{array}{l}\text { 2-years-and-nine-months- } \\
\text { old/female }\end{array}$ & 2 & $\begin{array}{l}\text { restricted diffusion in the basal ganglia and the } \\
\text { subcortical white matter of the frontal and } \\
\text { occipital lobes. }\end{array}$ & Brain death on day 73 \\
\hline $2[10]$ & 17-month-old/man & 106 & $\begin{array}{l}\text { cracking lesions in the white matter, brainstem } \\
\text { and cerebellum. }\end{array}$ & $\begin{array}{l}\text { Severe disability one and a } \\
\text { half years later }\end{array}$ \\
\hline 3 [11] & 4-year-old/female & 3 & $\begin{array}{l}\text { diffuse brain edema with extended involvement } \\
\text { of cortical and basal ganglia. }\end{array}$ & Recovery one year later \\
\hline $4[12]$ & 66-year-old/man & 15 & $\begin{array}{l}\text { white matter hyperintensities and multiple } \\
\text { microbleeds }\end{array}$ & Severe disability on day 60 \\
\hline $5[6]$ & 53-year-old/female & 28 & a small number of white matter lesions & $\begin{array}{l}\text { Moderate disability } 7 \text { month } \\
\text { later }\end{array}$ \\
\hline 6 [13] & 63-year-old / female & 27 & Diffuse white matter hyperintensities & Dead \\
\hline 7 [13] & 82-year-old / female & 8 & $\begin{array}{l}\text { Diffuse white matter hyperintensities and ischemic } \\
\text { lesion }\end{array}$ & Survival on day 100 \\
\hline 8 [13] & 73-year-old /man & 7 & $\begin{array}{l}\text { None of white matter hyperintensities and ischemic } \\
\text { lesion }\end{array}$ & Survival on day 100 \\
\hline 9 [13] & 57-year-old /man & 7 & $\begin{array}{l}\text { None of white matter hyperintensities and ischemic } \\
\text { lesion }\end{array}$ & Survival on day 100 \\
\hline 10 [13] & 55-year-old /man & 9 & Pathch/cinfluent white matter hyperintensities & Survival on day 100 \\
\hline $11[13]$ & 80-year-old / female & 9 & $\begin{array}{l}\text { Punctiform white matter hyperintensities and ischemic } \\
\text { lesion }\end{array}$ & Dead \\
\hline 12 [13] & 44-year-old /man & 12 & $\begin{array}{l}\text { None of white matter hyperintensities and ischemic } \\
\text { lesion }\end{array}$ & Survival on day 100 \\
\hline 13 [13] & 76-year-old / female & 4 & Punctiform white matter hyperintensities & Dead \\
\hline 14 [13] & 74-year-old / female & 10 & Pathch/cinfluent white matter hyperintensities & Survival on day 100 \\
\hline 15 [13] & 75-year-old /man & 10 & Diffuse white matter hyperintensities & Survival on day 100 \\
\hline 16 [13] & 54-year-old / female & 17 & $\begin{array}{l}\text { None of white matter hyperintensities and ischemic } \\
\text { lesion }\end{array}$ & Survival on day 100 \\
\hline 17 [13] & 60-year-old / female & 4 & Punctiform white matter hyperintensities & Survival on day 100 \\
\hline 18 [13] & 81-year-old /man & 5 & $\begin{array}{l}\text { Pathch/cinfluent white matter hyperintensities and } \\
\text { ischemic lesion }\end{array}$ & Survival on day 100 \\
\hline
\end{tabular}

(ADC) mapping, which can mark geometric tissue characteristics such as the size and shape of the cell structure, is not performed routinely in our hospital. This is a limitation in our case. In fact, ADC mapping is very useful in the consideration of the pathogenesis of brain lesions which show a reduction in acute neurological diseases, but elevations in acute vasogenic edema formation or chronic tissue destruction [14].

The treatment of SAE focuses on the appropriate management of sepsis, as SAE is not a direct infection in the CNS [8]. SAE can occur before sepsis is diagnosed. Thus, it is important to perform early investigations of and treatment for infection, thereby avoiding the development of severe SAE. Broadspectrum antibiotics, fluid resuscitation, and organ support are important for treating sepsis [15]. Extracorporeal blood purification therapies might improve clinical outcomes for patients with sepsis by removing inflammatory mediators and bacterial toxins from circulation and by restoring immune function at the cellular level [16-18]. The child in our study presented with fulminant clinical features and extended brain lesions that indicated severe SAE. Thus, TPE was implemented for our patient. The extensive white matter lesions in SAE can be reversed, which has been reported in a few cases. However, the lesions in our patient receded faster than those observed in these cases, and the clinical outcome was good upon accurate early diagnosis and effective treatment in our patient.

In conclusion, the case we describe demonstrates a rare presentation of brain MRI in a pediatric patient with hyperferritinemic sepsis within the first days after the onset of symptom. SAE can be a fatal complication of sepsis that requires immediate diagnosis and treatment. Therefore, MRI should be performed early to diagnose this fatal complication and could play 
important roles in the improvement of the clinical outcomes by early initiation with appropriate treatments. However, it is necessary to further accumulate patients with SAE to confirm that the utility of MRI, especially ADC, would be useful to construct a systematic treatment protocol for similar patients in worldwide in the future.

\section{Abbreviations \\ ADC: Apparent diffusion coefficient; AKI: Acute kidney injury; CLS: Capillary leak syndrome; CNS: Central nervous system; CRRT: Continuous Renal Replacement Therapy; CSF: Cerebrospinal fluid; CT: Computerized tomography; CWH: Continuous vena-venous hemofiltration; DIC: Disseminated intravascular coagulation; DWI: Diffusion-weighted imaging; ECG: Electrocardiograph; GCS: Glasgow coma scale score; HLH: Haemophagocytic lymphohistiocytosis; LVEF: Left ventricular ejection fraction; MODS: Multiple organ dysfunction syndrome; MRI: Magnetic resonance imaging; NORSE: New-onset refractory status epilepticus; PCT: Procalcitonin; SAE: Sepsis-associated encephalopathy; TPE: Therapeutic plasma exchange; WBC: White blood cell}

\section{Acknowledgments}

The authors thank the patient and her parents for allowing us to publish this case report.

\section{Authors' contributions}

Study concept and design: LH. Acquisition of data: RL and DX. Analysis and interpretation of data: $L H$ and DH. Drafting of the manuscript: $L H, S P$ and $\mathrm{DH}$. All authors have read and approved the manuscript.

\section{Funding}

This work was supported by Medical Scientific Research Foundation of Guangdong Province, China (grant No. A2018009). The funders had no role in the design of the study, collection, analysis, and interpretation of data. They had contributed in writing the manuscript.

\section{Availability of data and materials}

All primary data supporting the findings of this study are available within this article.

\section{Ethics approval and consent to participate}

We declare that ethics approval was not required for this case report.

\section{Consent for publication}

Written informed consent was obtained from the parents of the patient for publication of this case report.

\section{Competing interests}

The authors declare that they have no competing interests.

Received: 27 September 2019 Accepted: 26 February 2020

Published online: 02 March 2020

\section{References}

1. Sharshar T, Carlier R, Bernard F, Guidoux C, Brouland J, Nardi O, de la Grandmaison GL, Aboab J, Gray F, Menon D, et al. Brain lesions in septic shock: a magnetic resonance imaging study. Intens Care Med. 2007;33(5): 798-806.

2. Zhang L, Wang X, Ai Y, Guo Q, Huang L, Liu Z, Yao B. Epidemiological features and risk factors of sepsis-associated encephalopathy in intensive care unit patients: 2008-2011. Chinese Med J-Peking. 2012;125(5):828-31.

3. Hadem J, Hafer C, Schneider AS, Wiesner O, Beutel G, Fuehner T, Welte T, Hoeper MM, Kielstein JT. Therapeutic plasma exchange as rescue therapy in severe sepsis and septic shock: retrospective observational single-centre study of 23 patients. BMC Anesthesiol. 2014;14:24. https://doi.org/10.1186/ 1471-2253-14-24. PMID: 24708653; PMCID: PMC3986467.

4. Trinka E, Cock H, Hesdorffer D, Rossetti AO, Scheffer IE, Shinnar S, Shorvon S, Lowenstein DH. A definition and classification of status epilepticus--report of the ILAE task force on classification of status Epilepticus. Epilepsia. 2015 56(10):1515-23.

5. Hirsch L, Gaspard N, van Baalen A, Nabbout R, Demeret S, Loddenkemper T, Navarro V, Specchio N, Lagae L, Rossetti AO, et al. Proposed consensus definitions for new-onset refractory status epilepticus (NORSE), febrile infection-related epilepsy syndrome (FIRES), and related conditions. Epilepsia. 2018;59(4):739-44.

6. Luitse MJ, van Asch CJ, Klijn CJ. Deep coma and diffuse white matter abnormalities caused by sepsis-associated encephalopathy. Lancet. 2013; 381(9884):2222.

7. Sandquist MK, Clee MS, Patel SK, Howard KA, Yunger T, Nagaraj UD, Jones BV, Fei L, Vadivelu S, Wong HR. High frequency of neuroimaging abnormalities among pediatric patients with Sepsis who undergo neuroimaging. Pediatr Crit Care Med. 2017;18(7):607-13.

8. Gofton TE, Young GB. Sepsis-associated encephalopathy. Nat Rev Neurol. 2012;8(10):557-66.

9. lacobone E, Bailly-Salin J, Polito A, Friedman D, Stevens RD, Sharshar T. Sepsis-associated encephalopathy and its differential diagnosis. Crit Care Med. 2009:37(10 Suppl):S331-6.

10. Kondo A, Sugiura C, Fujii Y, Inoue T, Maegaki Y, Ohno K. Fulminant sepsisassociated encephalopathy in two children: serial neuroimaging findings and clinical course. Neuropediatrics. 2009:40(4):157-61.

11. Chacqueneau AL, Desrumaux-Becquet A, Debillon T, NGuyen MA, Bessaguet S, Bost-Bru C, Leroy P, Wroblewski I. A child with sepsis-associated encephalopathy. Arch Pediatr. 2013;20(10):1120-5.

12. Shindo A, Suzuki K, Iwashita Y, Tomimoto H. Sepsis-associated encephalopathy with multiple microbleeds in cerebral white matter. Am J Med. 2018;131(7):e297-8

13. Ehler J, Barrett LK, Taylor V, Groves M, Scaravilli F, Wittstock M, Kolbaske S, Grossmann A, Henschel J, Gloger M, et al. Translational evidence for two distinct patterns of neuroaxonal injury in sepsis: a longitudinal, prospective translational study. Crit Care. 2017;21(1):262.

14. Gass A, Niendorf T, Hirsch JG. Acute and chronic changes of the apparent diffusion coefficient in neurological disorders--biophysical mechanisms and possible underlying histopathology. J Neurol Sci. 2001;186(Suppl 1):S15-23.

15. Coopersmith CM, De Backer D, Deutschman CS, Ferrer R, Lat I, Machado FR, Martin GS, Martin-Loeches I, Nunnally ME, Antonelli M, et al. Surviving sepsis campaign: research priorities for sepsis and septic shock. Intensive Care Med. 2018:44(9):1400-26.

16. Shum HP, Yan WW, Chan TM. Extracorporeal blood purification for sepsis. Hong Kong Med J. 2016;22(5):478-85.

17. Nguyen TC, Han YY, Kiss JE, Hall MW, Hassett AC, Jaffe R, Orr RA, Janosky J, Carcillo JA. Intensive plasma exchange increases a disintegrin and metalloprotease with thrombospondin motifs-13 activity and reverses organ dysfunction in children with thrombocytopenia-associated multiple organ failure. Crit Care Med. 2008;36(10):2878-87.

18. De Simone N, Racsa L, Bevan S, Matevosyan K, Valley T, Girod C, Sarode R. Therapeutic plasma exchange in the management of sepsis and multiple organ dysfunction syndrome: A report of three cases. J Clin Apheresis. 2014; 29(2):127-31.

\section{Publisher's Note}

Springer Nature remains neutral with regard to jurisdictional claims in published maps and institutional affiliations.
Ready to submit your research? Choose BMC and benefit from:
- fast, convenient online submission
- thorough peer review by experienced researchers in your field
- rapid publication on acceptance
- support for research data, including large and complex data types
- gold Open Access which fosters wider collaboration and increased citations
- maximum visibility for your research: over $100 \mathrm{M}$ website views per year
At BMC, research is always in progress.
Learn more biomedcentral.com/submission 